\title{
Atrazine, triketone herbicides, and their degradation products in sediment, soil and surface water samples in Poland
}

\author{
Hanna Barchanska $^{1} \cdot$ Marcin Sajdak $^{2} \cdot$ Kornelia Szczypka $^{1}$ - Angelika Swientek ${ }^{1}$. \\ Martyna Tworek ${ }^{1} \cdot$ Magdalena Kurek $^{1}$
}

Received: 23 April 2016/Accepted: 28 September 2016/Published online: 14 October 2016

(C) The Author(s) 2016. This article is published with open access at Springerlink.com

\begin{abstract}
The aim of this study was to monitor the sediment, soil and surface water contamination with selected popular triketone herbicides (mesotrione (MES) and sulcotrione(SUL)), atrazine (ATR) classified as a possible carcinogen and endocrine disrupting chemical, as well as their degradation products, in Silesia (Poland). Seventeen sediment samples, 24 soil samples, and 64 surface water samples collected in 2014 were studied. After solid-liquid extraction (SLE) and solid phase extraction (SPE), analytes were determined by high-performance liquid chromatography (HPLC) with diode array detection (DAD). Ten years after the withdrawal from the use, ATR was not detected in any of the collected samples; however, its degradation products are still present in $41 \%$ of sediment, $71 \%$ of soil, and $8 \%$ of surface water samples. SUL was determined in $85 \%$ of soil samples; its degradation product (2-chloro-4-(methylosulfonyl) benzoic acid (CMBA)) was present in $43 \%$ of soil samples. In $17 \%$ of sediment samples, CMBA was detected. Triketones were detected occasionally in surface water samples. The chemometric analysis (clustering analysis (CA), single-factor analysis of variance (ANOVA), N-Way ANOVA) was applied
\end{abstract}

Responsible editor: Philippe Garrigue

Electronic supplementary material The online version of this article (doi:10.1007/s11356-016-7798-3) contains supplementary material, which is available to authorized users.

Hanna Barchanska

hanna.barchanska@polsl.pl

1 Department of Inorganic, Analytical Chemistry and Electrochemistry, Faculty of Chemistry, Silesian University of Technology, B. Krzywoustego 6 Str, 44-100 Gliwice, Poland

2 Institute for Chemical Processing of Coal, 1 Zamkowa St, 41-803 Zabrze, Poland to find relations between selected soil and sediment parameters and herbicides concentration. In neither of the studied cases a statistically significant relationship between the concentrations of examined herbicides, their degradation products and soil parameters (organic carbon (OC), $\mathrm{pH}$ ) was observed.

Keywords Triketones $\cdot$ Atrazine $\cdot$ Herbicide degradation products $\cdot$ Soil $\cdot$ Sediment $\cdot$ Surface water

\section{Introduction}

Since their discovery in the 1940s, pesticides have greatly contributed to improving the yield and quality of crops and to ensuring their production. Atrazine ((2-chloro-4ethylamino-6-isopropylamino-1,3,5-triazine, ATR), a triazine compound, has been frequently used (about 30,000 tons annually) as a herbicide for maize crops (Hase et al. 2008). ATR accumulate in leaves and meristems, where, in sensitive plant species, it inhibits the Hill reaction by blocking photosynthesis by binding with tyrosinase, the enzyme responsible for the oxidation of polyphenols to quinones, which, in consequence, lead to annihilation of weeds (Mou et al. 2011). ATR inhibits the growth of weeds and algae by interfering with the normal function of photosynthesis. The widespread and long-term use of ATR resulted in its high residue levels in soil, which further causes the surface and groundwater contamination via rain runoff and leakage ( $\mathrm{Ji}$ et al. 2015).

ATR is degraded in the environment to a range of degradation products: hydroxyatrazine (2-hydroxy-4-ethylamino-6isopropylamino-1,3,5-triazine, HA); deethylatrazine (2chloro-4-amino-6-ethylamino-1,3,5-triazine, DEA); deisopropylatrazine (2-chloro-4-ethylamino-6-amino-1,3,5triazine, DIA) and desethyldesisopropylatrazine (2-chloro4,6-diamino-1,3,5-triazine, DEDIA). These compounds, 
similar to parent one, are persistent in the environment and toxic (potent endocrine disrupters) (Ghanem et al. 2008; Hu and Cheng 2013).

Due to ATR high toxicity (possible carcinogen and endocrine disrupting chemical to numerous organisms), persistence and ability to transfer in the environment (Roustan et al. 2014; Yixin et al. 2014), it was banned in several European countries in 2003 (still widely used in the USA and another region of the world). As a replacement, new selective herbicides have been developed. Among them, the triketone class of herbicides, mainly mesotrione and sulcotrione play the most important role (Calvayrac et al. 2012; Chaabane et al. 2008; Jović et al. 2013; Tawk et al. 2015).

Synthetic $\beta$-triketone herbicides inhibit plant 4hydroxyphenylpyruvate dioxygenase (HPPD) activity that leads to decrease in the pigment production, leaves bleaching and finally, death of the plant (Jović et al. 2013; Owens et al. 2013). They are used to control the majority of annual broadleaf weeds, with limited activity on grasses. Among the group of triketone herbicides, the most frequently used are mesotrione (2-(4-methylsulfonyl2-nitrobenzoyl)-1, 3-cyclohexanedione, MES) and sulcotrione (2-[2-chloro-4-(methylsulfonyl)benzoyl]-1,3cyclohexanedione, SUL).

MES was developed by Syngenta Crop Protection and registered in Europe in 2000, whereas SUL was introduced by Zeneca Ag Products (now Syngenta Crop Protection) and first registered for use in France in 1993. Both MES and SUL have acidic properties (pKa of around 3), which are determinant for their environmental behaviour. In the environment, MES is degraded into two main by-products: 4-(methylsulfonyl)-2-nitrobenzoic acid (MNBA) and 2-amino-4-(methylsulfonyl)benzoic acid (AMBA), whereas 2chloro-4-(methylosulfonyl) benzoic acid (CMBA) and 1,3cyclohexanedione (CHD) are the degradation products of SUL (Trivella et al. 2015).

According to numerous literature reports (Barchanska et al. 2014; Bardot et al. 2015; Crouzet et al. 2010, 2013; Joly et al. 2013), triketones and their degradation products negatively influence microorganisms and aquatic plants. MES exhibits moderate retention capacity in different soils and may be leached to surface water (Chaabane et al. 2008; Dyson et al. 2002). Moreover, MES is also classified by the EEC as toxicologically dangerous for the environment (Batisson et al. 2009). MES can persist in the soil up to 32 days after application depending on the environmental conditions and type of soil (Dyson et al. 2002). Its residues affect several sensitive crops, such as snap beans, pickling cucumber, cabbage and pepper (Yu et al. 2015). Moreover, it was shown that the AMBA had a higher toxicity than the parent compound (Barchanska et al. 2014; Bonnet et al. 2008).

Although SUL degradation products had no herbicide activity, they present toxicity towards unicellular organisms different of sulcotrione toxicity (Ter Halle et al. 2009; Wiszniowski et al. 2009). According to Goujon et al. (2014), SUL possesses genotoxic properties against Allium cepa $\mathrm{L}$. The detailed physicochemical parameters of all abovementioned herbicides and their degradation products are placed in Table 1.

During the agricultural treatments, pesticides could be directly reached by the cultures or sorbed into the soil particles. The behaviour of pesticides in soils is governed by a variety of complex dynamic physical, chemical and biological processes, including; volatilization, sorption-desorption, chemical and biological degradation, uptake by plants, run-off and leaching (Alekseeva et al. 2014). All these processes depend on the physicochemical properties of pesticide, environmental conditions, microorganisms and properties of soil, and they directly control the transport of pesticides within the soil and their transfer from the soil to water and sediments. The water contamination with pesticides is constantly monitored by the European Union. It has established a number of regulations and directives, such as the Directive 2000/60/EC, which defines the framework for the management and the restoration of the status of surface and superficial waters for 2015 (European Union 2000, 2009; Rocaboy-Faquet et al. 2014). The maximum allowable pesticide concentration in drinking water cannot exceed $0.1 \mu \mathrm{g} / \mathrm{L}$.

From the surface waters, pesticides are deposited into bottom sediments. Pesticides sorbed on sediments are hardly bioavailable; however, they may have an influence on benthos organisms. As a result of environmental condition changes (increased temperature, $\mathrm{pH}$, etc.) or floods, the pesticides accumulated in the sediments are in an uncontrolled way released back into the environment.

Therefore, it is necessary to monitor the concentration of pesticide residues in soil, water and sediments as well as aquatic organisms, since from these matrices, pesticides are transferred into the air and food of plant origin, which constitutes a direct threat to human health.

According to our best knowledge, there is a scarce current data concerning the monitoring of ATR in European environment (Price et al. 2006; Caquet et al. 2013; Farlin et al. 2013, Ouyang et al. 2016a). The main attention is paid to degradation and transformation of ATR during water treatment processes (Baranda et al. 2012; Lekkerkerker-Teunissen et al. 2012; Yixin et al. 2014; Cheng et al. 2016), its toxicity (Roustan et al. 2014) or sorption behaviour in soil (Prado et al. 2014; Nachimuthu et al. 2016; Ouyang et al. 2016b). Similarly, monitoring information concerning triketone herbicides and their degradation products (Alferness and Wiebe 2002; Freitas et al. 2004; Moschet et al. 2014) are lacking.

In conclusion, according to our literature review as well as studies conducted by Farlin et al. (2013) the historical and the spatial monitoring of the pesticide residues after several halflife cycles has seldom been conducted. Such investigations are 
Table 1 Characteristic of investigated herbicides and their degradation products

\begin{tabular}{|c|c|c|c|c|c|c|}
\hline Name & Structure & $\begin{array}{c}\text { Solubility in } \\
\text { water }[\mathrm{mg} / \mathrm{L}]\end{array}$ & $\begin{array}{c}\operatorname{logk}_{\text {ow }} \\
\mathrm{pH} 7\end{array}$ & $\mathrm{pK}_{\mathrm{a}}$ & $\begin{array}{l}\text { Half-life in } \\
\text { soil [day] }\end{array}$ & $\begin{array}{l}\text { Retention } \\
\text { time [min] }\end{array}$ \\
\hline $\begin{array}{c}\text { ATR } \\
\text { (2-chloro-4-ethylamiono- } \\
\text { 6- isopropylamino-1,3,5- } \\
\text { triazine) }\end{array}$ & & 35 & 2.7 & 1.7 & 75 & 9.58 \\
\hline $\begin{array}{c}\text { HA } \\
\text { (2-hydroxy-4-ethylamino- } \\
\text { 6-isopropylamino-1,3,5- } \\
\text { triazine) }\end{array}$ & & 3.9 & 2.1 & 4.9 & 164 & 7.21 \\
\hline $\begin{array}{c}\text { DEA } \\
\text { (2-chloro-4-amino-6- } \\
\text { ethylamino-1,3,5-triazine) }\end{array}$ & & 3200 & 1.5 & 1.3 & 4.5 & 7.89 \\
\hline $\begin{array}{c}\text { DIA } \\
\text { (2-chloro-4-ethylamino-6- } \\
\text { amino-1,3,5-triazine) }\end{array}$ & & 670 & 1.2 & 1.2 & $\begin{array}{c}\text { not } \\
\text { reported }\end{array}$ & 6.56 \\
\hline $\begin{array}{c}\text { DEDIA } \\
\text { (2-chloro-4,6-diamino- } \\
\text { 1,3,5-triazine) }\end{array}$ & & 600 & 0.3 & 1.5 & $\begin{array}{c}\text { not } \\
\text { reported }\end{array}$ & 1.57 \\
\hline $\begin{array}{c}\text { MES } \\
\text { (2-(4-methylsulfonyl-2- } \\
\text { nitrobenzoyl)-1, 3- } \\
\text { cyclohexanedione) }\end{array}$ & & 160 & 0.11 & 3.12 & 32 & 26.58 \\
\hline $\begin{array}{c}\text { MNBA } \\
\text { 4-(methylsulfonyl)-2- } \\
\text { nitrobenzoic acid }\end{array}$ & & not reported & $1.51 *$ & $0.19 *$ & 7.5 & 7.23 \\
\hline $\begin{array}{c}\text { AMBA } \\
\text { 2-amino-4- } \\
\text { (methylsulfonyl) } \\
\text { benzoic acid }\end{array}$ & & not reported & $4.24 *$ & $0.38 *$ & 72 & 14.50 \\
\hline $\begin{array}{c}\text { SUL } \\
\text { 2-[2-chloro-4- } \\
\text { (methylsulfonyl)benzoyl]- } \\
\text { 1,3-cyclohexanedione }\end{array}$ & & 165 & $3.13 *$ & $-0.20 *$ & 25 & 27.58 \\
\hline $\begin{array}{c}\text { CMBA } \\
\text { 2-chloro-4- } \\
\text { (methylosulfonyl) } \\
\text { benzoic acid }\end{array}$ & & 60000 & -0.2 & $\begin{array}{c}\text { not } \\
\text { reported }\end{array}$ & 24 & 12.57 \\
\hline $\begin{array}{c}\text { CHD } \\
\text { 1,3-cyclohexanedione }\end{array}$ & & not reported & 5.26 & -0.99 & $\begin{array}{c}\text { not } \\
\text { reported }\end{array}$ & 9.08 \\
\hline
\end{tabular}

* - octanol - water partition constants and ionization constant were obtained from ACD/Labs (SciFinder). sitem.herts.ac.uk/aeru/iupac/index.htm (access: 22.10.2015)

*Octanol-water partition constants and ionization constant were obtained from ACD/Labs (SciFinder) 
of special importance since pesticides, that are slowly degraded in soil, are potential markers that could prove useful for a number aspects pertaining to pesticide fate modelling. Therefore, the objective of the present research was to conduct the monitoring studies concerning the presence of ATR, MES and SUL, and their degradation products in sediments (17 samples), soil (22 samples) and surface water (64 samples) collected in 2014 in the Silesia region (Poland).

\section{Material and methods}

\section{Apparatus and chemicals}

Herbicide standards and their degradation products were supplied by Sigma-Aldrich, Germany (ATR, DIA, DEA, DEDIA, HA, MES, SUL, TEMB and TEMB MET); Santa Cruz Biotechnology, Germany (AMBA and MNBA); and Dr. Ehrenstorfer Quality, Germany (CHD and CMBA). Stock standard solutions for each compound were prepared in methanol at $1 \mathrm{mg} / \mathrm{mL}$ and stored in glass vials at $4{ }^{\circ} \mathrm{C}$ in the dark. Acetonitrile, trifluoroacetic acid (TFA), and water (all highperformance liquid chromatography (HPLC) grade) were from Merck, Germany. Acetic acid (glacial), acetonitrile, dichloromethane, ethyl acetate, methanol, and hydrochloric acid conc. (all analytical grade) were purchased from Stanlab, Poland.

The chromatographic system used (Merck Hitachi, Germany) consisted of a Hitachi LaChrom Elite L-2130 pump and Hitachi LaChrom Elite L-2455 photodiode array detector (DAD). The stationary-phase column was LiChroCART Purospher RP-18e (125 × 3 mm, $5 \mu \mathrm{m}$, Merck).

For solid phase extraction (SPE), the following sorbents were applied: OASIS® HLB (500 mg, $6 \mathrm{~mL}$; Waters,
Milford, USA), SDB (500 mg, $3 \mathrm{~mL}$ ) and C18 (500 mg, $3 \mathrm{~mL}$ ). These sorbents were used on a 12-fold vacuum extraction box (BAKERBOND® SPE J.T. Baker, Philipsburg, USA). Nylon membrane filters were also obtained from J.T. Baker. Chemometric analysis was performed using MATLAB R2015b software.

\section{Samples}

Seventeen sediment, 24 soil and 64 surface water samples, collected in 2014 were studied.

River sediment samples were collected according to the standards ISO 5667-15:2009 (2009) in September and October 2014. From Kłodnica River, sediment samples (nos. 1-7) were taken along the river from depths $0.3 \mathrm{~m}$ and $1.2 \mathrm{~m}$.

Soil samples were collected according to ISO 103814:2007 (2007) in July and August 2014. Before all experiments, stones and plant fragments were removed, the soils and sediments were air-dried, until the constant mass and sieved through $0.2 \mathrm{~mm}$ mesh.

Water samples were collected periodically every month (January 2014-September 2014). Raw water samples, collected according to PN-ISO 5667-4: 2003 and PN-ISO 5667-6: 2003, were stored with added acid ( $\mathrm{pH} 2.5)$ in the dark at $4{ }^{\circ} \mathrm{C}$. Samples were filtered at room temperature through a Buchner funnel and then nylon membrane filters $(0.2 \mu \mathrm{m})$.

The samples were collected mainly in the Silesian Upland (Poland) from agricultural, forest and industrial regions, as well as in agricultural areas of central and south Poland. During the whole period of sampling, the level of atmospheric precipitation was monitored in the investigated regions. The detailed information about the sample origin is placed in Fig. 1 and Table 2 .

Fig. 1 Samples origin

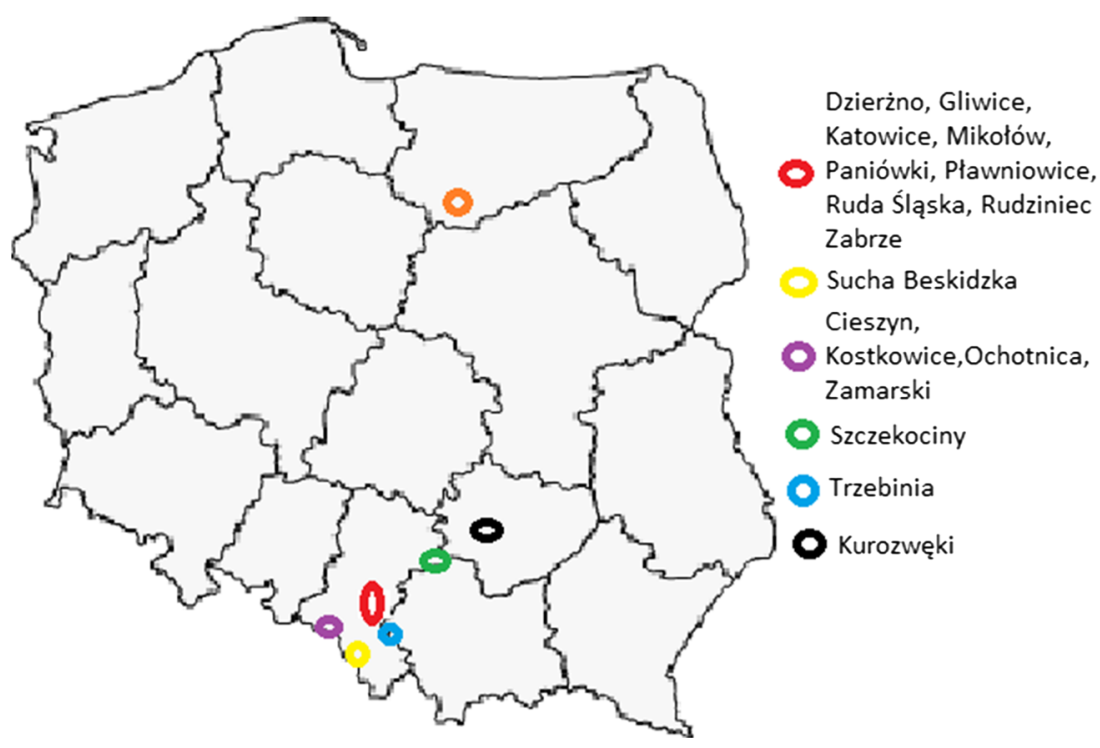




\section{Analytical procedures}

\section{Triazines determination}

From soil and water samples, atrazine and its derivative was extracted according to Barchanska et al. (2012). Ten grams of soil was extracted with $30 \mathrm{~mL}$ of the mixture ACN:0.1 M $\mathrm{HCl}(9: 1 v / v)$; after filtering, the extract was shaken with dichloromethane $(2 \times 5 \mathrm{~mL})$. After phase separation, the organic extract was evaporated to dryness, dissolved in $5 \mathrm{~mL}$ of $0.1 \mathrm{M} \mathrm{HCl}$ and concentrated by solid phase extraction (SPE). Silica gel modified with octadecyl groups (C18) was applied as a sorbent. The sorbent was conditioned with methanol $(3 \mathrm{~mL}), 2 \%$ acetic acid in acetonitrile $(3 \mathrm{~mL})$ and $2 \%$ acetic acid in water $(3 \mathrm{~mL})$. The analytes were eluted by means of (in sequence) methanol $(3 \mathrm{~mL})$, ethyl acetate $(2 \mathrm{~mL})$ and $0.2 \%$ acetic acid in acetonitrile $(2 \mathrm{~mL})$. The same extraction procedure was applied for sediment samples. The values of analytes recoveries from sediment samples were comparable to those obtained from soil samples. From water samples (1 L), triazines were extracted on SDB sorbents. The sorbnet was conditioned with methanol $(3 \mathrm{~mL})$, dichloromethane $(10 \mathrm{~mL})$, acetonitrile $(10 \mathrm{~mL})$ and water $(10 \mathrm{~mL})$. The analytes elution was conducted by means of mixture of methanol and ethyl acetate $(6 \mathrm{~mL}$, $1: 1, v / v)$ followed by methanol $(5 \mathrm{~mL})$ and acetonitrile $(5 \mathrm{~mL})$. The detailed parameters of these extraction procedures are placed in Barchanska et al. (2012).

The mobile phase for triazines separation consisted of $0.05 \%$ TFA in water (A), water (B) and $0.05 \%$ TFA in acetonitrile $(\mathrm{C})$. The gradient profile during separation was as follows: $0 \mathrm{~min}: 95 \% \mathrm{~A}, 5 \% \mathrm{C}$, flow: $1 \mathrm{~mL} / \mathrm{min} ; 2 \mathrm{~min}$ : $95 \%$ A, $5 \%$ C, flow: $1 \mathrm{~mL} / \mathrm{min} ; 5$ min: $75 \% \mathrm{~A}, 25 \% \mathrm{C}$, flow: $1 \mathrm{~mL} / \mathrm{min}$; $8 \mathrm{~min}: 75 \% \mathrm{~B}, 25 \% \mathrm{C}$, flow: $1 \mathrm{~mL} / \mathrm{min}$; $12 \mathrm{~min}: 50 \% \mathrm{~B}, 50 \% \mathrm{C}$, flow: $0.5 \mathrm{~mL} / \mathrm{min} ; 18 \mathrm{~min}$ : $90 \% \mathrm{~B}, 10 \% \mathrm{C}$, flow: $1 \mathrm{~mL} / \mathrm{min}$ and $25 \mathrm{~min}: 95 \% \mathrm{~A}$, $5 \%$ C, flow: $1 \mathrm{~mL} / \mathrm{min}$ (Barchanska et al. 2012). Method fortification recoveries for soil and sediment were in the range of 80-97\%, whereas for water samples, 71-97\% depending on the analyte. The limits of detection (LOD) were $2-88 \mathrm{ng} / \mathrm{g}$ and $0.04-0.61 \mu \mathrm{g} / \mathrm{L}$ for soil (sediment) and water samples, respectively.

\section{Triketones determination}

The detailed procedure for triketone extraction from soil and sediment samples is described in Barchanska et al. (2016). Briefly, soil and sediment samples (10 g) were mixed with acetonitrile $(30 \mathrm{~mL})$ and shaken for $30 \mathrm{~min}$. Next, the extracts were filtered. The filtrate was extracted with dichloromethane $(2 \times 5 \mathrm{~mL})$. After phase separation, the organic layer was evaporated to dryness, and the residue was dissolved in $0.1 \mathrm{M} \mathrm{HCl}(5 \mathrm{~mL})$. The final purification and concentration of the extract was conducted by means of SPE. The obtained solution was transferred on SDB sorbent, previously conditioned with water $(3 \mathrm{~mL})$ and methanol $(3 \mathrm{~mL})$. The analytes were eluted by means of methanol $(2 \mathrm{~mL})$, ethyl acetate $(2 \mathrm{~mL})$ and $4 \%$ acetic acid in acetonitrile $(3 \mathrm{~mL})$. After elution, the solvents were evaporated to dryness and the residue was dissolved in $0.5 \mathrm{~mL}$ of methanol before chromatographic analyses.

Triketones from water samples were extracted according to the following procedure: a water sample $(250 \mathrm{~mL})$ was aspirated through the HLB sorbent, previously conditioned with methanol $(6 \mathrm{~mL})$ and water $(6 \mathrm{~mL})$ Analytes were eluted by means of the mixture acetonitrile/methanol ( $6 \mathrm{~mL}, 1: 1, v / v)$. After analyte elution, the extract was evaporated to dryness under a stream of nitrogen and the residue was dissolved in $1 \mathrm{~mL}$ of methanol. The detailed validation data of this procedure are available from Barchanska et al. (2014).

The mobile phase used for triketones separation consisted of $0.05 \%$ TFA in water (A) and acetonitrile (B). The gradient profile during separation was as follows: $0 \mathrm{~min}: 100 \% \mathrm{~A}$, flow: $0.7 \mathrm{~mL} / \mathrm{min}$; $28 \mathrm{~min}: 60 \% \mathrm{~A}, 40 \% \mathrm{~B}$, flow: $0.7 \mathrm{~mL} /$ min and $35 \mathrm{~min}: 30 \% \mathrm{~A}, 70 \% \mathrm{~B}$, flow: $1.0 \mathrm{~mL} / \mathrm{min}$. Barchanska et al. (2014).

The recoveries of triketone herbicides from soil were in the range of 67-107\%, whereas for sediment were in the range of 78-98\%. LOD was 4-72 ng/g and 5-60 ng/g for soil and sediment, respectively. The triketones recoveries from water samples were in the range of 52 to $96 \%$, whereas LOD was in the range of $0.06-0.26 \mu \mathrm{g} / \mathrm{L}$.

The chromatograms of pesticide free and spiked with standards sediment, soils and water samples are presented in Figs. 1SM, 2SM and 3SM, respectively, in Supplementary Material.

To identify target compounds, retention times and UV spectra of sample components and standards were compared as well as standards addition to sample extract was conducted. Moreover, in ambiguous cases, the derivative spectrophotometry was applied to confirm the purity of the chromatogram peak (data not shown). The detailed validation parameters are placed in Table 3. Intra-day precision (repeatability) is referred as within-day precision, whereas inter-day precision is referred to between-day precision. In all cases for the quantitative analysis, the peak area was applied.

\section{Organic carbon content and $\mathrm{pH}$}

Since $\mathrm{pH}$ and organic carbon content (OC) have an influence on pesticides stability in soil and sediment, these parameters were determined according to PN-ISO 10390: 2007 and PNISO 14235 (1997). All calculations and the final results are expressed per $1 \mathrm{~g}$ of air-dried soil (sediment). 
Table 2 Samples origin - general information

\begin{tabular}{|c|c|c|c|}
\hline \multicolumn{4}{|c|}{ Sediment samples } \\
\hline No. & Date & Place/river & Remarks \\
\hline 1 & September 2014 & Katowice Giszowiec-Kłodnica & forest, marshy area \\
\hline 2 & September 2014 & Gliwice Łabędy-Kłodnica & $\begin{array}{l}\text { water treatment plant, maize and } \\
\text { potatoes cultivations }\end{array}$ \\
\hline 3 & September 2014 & Ruda Śląska-Kłodnica & potatoes, maize and corn cultivations \\
\hline 4 & September 2014 & Gliwice-Kłodnica & recreational area \\
\hline 5 & September 2014 & Zabrze Makoszowy-Kłodnica & potatoes cultivation \\
\hline 6 & September 2014 & Zabrze Makoszowy-Kłodnica & wheat, rape, rye cultivations \\
\hline 7 & September 2014 & Katowice-Kłodnica & forest, marshy area \\
\hline 8 & October 2014 & Ochotnica Dolna-Ochotniczanka & meadow \\
\hline 9 & October 2014 & Zamarski- Lutnia & meadow \\
\hline 10 & October 2014 & Kostkowice-stream & meadow \\
\hline 11 & October 2014 & Cieszyn-Olza & industrialized area, water treatment plant \\
\hline 12 & October 2014 & Cieszyn-Bobrówka & industrialized area power plant \\
\hline 13 & October 2014 & Cieszyn-Młynówka & industrialized area power plant \\
\hline 14 & October 2014 & Cieszyn-Przykopa & wheat cultivation \\
\hline 15 & September 2014 & Tychy-Gostyń & potatoes cultivation \\
\hline 16 & September 2014 & Tychy-Mleczna & maize cultivation \\
\hline 17 & September 2014 & Katowice-Rawa & water treatment plant \\
\hline \multicolumn{4}{|c|}{ Soil samples } \\
\hline No & Date & Place & Remarks \\
\hline $18-21$ & July 2014 & Szczekociny I-IV & potatoes cultivation \\
\hline $22-24$ & August 2014 & Sucha Beskidzka I-III & meadow, potatoes, cucumber and cultivations \\
\hline 25 & August 2014 & Katowice Kostuchna & wheat cultivation, forest \\
\hline $26-28$ & August 2014 & Tychy Wilkowyje I-III & wheat cultivation \\
\hline 29 & August 2014 & Katowice Kostuchna & meadow \\
\hline 30 & August 2014 & Paniówki & maize cultivation \\
\hline 31 & August 2014 & Mikołów & maize cultivation \\
\hline 32 & August 2014 & Ruda Śląska & forest \\
\hline $33-37$ & August 2014 & Kurozwęki I-V & potatoes cultivation \\
\hline 38 & October 2014 & Kozłowo & maize cultivation \\
\hline 39 & October 2014 & Rudziniec & maize cultivation \\
\hline 40 & August 2014 & Trzebinia & maize cultivation \\
\hline 41 & August 2014 & Gliwice & potatoes cultivation \\
\hline \multicolumn{4}{|c|}{ Water samples } \\
\hline 42 & January-September (monthly) 2014 & Pławniowice Lake & $\begin{array}{l}\text { artificial lake, surrounded by agricultural } \\
\text { area (the cultivation of cereals) }\end{array}$ \\
\hline 43 & January-September (monthly) 2014 & Dzierżno Lake & $\begin{array}{l}\text { artificial lake, surrounded by farmland } \\
\text { (the cultivation of cereals), powered } \\
\text { by the waters of Kłodnica river }\end{array}$ \\
\hline 44 & January-September (monthly) 2014 & Rudziniec/breeding pond & $\begin{array}{l}\text { natural lake, surrounded by agricultural } \\
\text { area (the cultivation of cereals) }\end{array}$ \\
\hline 45 & January-September (monthly) 2014 & Dziergowice/Dziergowice Lake & $\begin{array}{l}\text { artificial lake, surrounded by farmland } \\
\text { (the cultivation of cereals), powered } \\
\text { by the waters of Bierawka river }\end{array}$ \\
\hline 46 & January-September (monthly) 2014 & Rudziniec/Kłodnica River & $\begin{array}{l}\text { river flowing through the Silesian Upland, } \\
\text { place of sampling - agricultural area }\end{array}$ \\
\hline 47 & January-September (monthly) 2014 & Rudziniec/drainage ditch & a drainage ditch in agricultural area \\
\hline 48 & January-September (monthly) 2014 & Rudziniec/ pond in forest & natural lake, surrounded by forest \\
\hline
\end{tabular}


Table 3 Quality parameters of the method

\begin{tabular}{|c|c|c|c|c|c|c|}
\hline \multicolumn{7}{|l|}{ Soil } \\
\hline Analyte & Equation & $R^{2}$ & LOD $[n g / g]$ & Recovery [\%] & $\begin{array}{c}\text { Intra-day [CV \%] } 0.05 \\
\mu \mathrm{g} / \mathrm{g}(5 \mu \mathrm{g} / \mathrm{g})\end{array}$ & $\begin{array}{c}\text { Inter-day [CV \%] } 0.05 \\
\mu \mathrm{g} / \mathrm{g}(5 \mu \mathrm{g} / \mathrm{g})\end{array}$ \\
\hline ATR & $y=8.60 \times 10^{5} x-3.50 \times 10^{5}$ & 0.9989 & 0.02 & $85 \pm 3$ & $6.7(5.1)$ & $7.0(5.8)$ \\
\hline DEDIA & $y=1.46 \times 10^{4} x+4.00 \times 10^{3}$ & 0.9998 & 0.88 & $91 \pm 4$ & $7.0(6.2)$ & $7.7(6.8)$ \\
\hline DEA & $y=3.60 \times 10^{5} x-4.79 \times 10^{4}$ & 0.9995 & 0.05 & $80 \pm 3$ & $5.8(4.7)$ & $5.8(4.9)$ \\
\hline DIA & $y=3.90 \times 10^{5} x+3.95 \times 10^{4}$ & 0.9985 & 0.04 & $97 \pm 7$ & $6.0(4.9)$ & $6.8(5.8)$ \\
\hline HA & $y=1.97 \times 10^{5} x-1.98 \times 10^{4}$ & 0.9972 & 0.05 & $86 \pm 5$ & $6.6(6.3)$ & $6.6(6.4)$ \\
\hline MES & $y=21.88 \times 10^{4} x-40.71 \times 10^{4}$ & 0.9979 & 22 & $106 \pm 7$ & $5.6(4.7)$ & $6.2(5.8)$ \\
\hline AMBA & $y=74.09 \times 10^{4} x-10.21 \times 10^{4}$ & 0.9935 & 4 & $76 \pm 4$ & $5.8(3.7)$ & $6.4(6.0)$ \\
\hline MNBA & $y=35.62 \times 10^{4} x-38.12 \times 10^{4}$ & 0.9994 & 5 & $75 \pm 2$ & $7.8(5.9)$ & $8.3(7.5)$ \\
\hline SUL & $y=10.35 \times 10^{4} x+9.86 \times 10^{4}$ & 0.9958 & 15 & $107 \pm 4$ & $6.9(5.1)$ & $7.3(6.9)$ \\
\hline CMBA & $y=13.76 \times 10^{4} x+33.11 \times 10^{4}$ & 0.9977 & 72 & $67 \pm 12$ & $7.0(4.5)$ & $7.0(6.8)$ \\
\hline \multicolumn{7}{|c|}{ Sediment } \\
\hline Analyte & Equation & $R^{2}$ & LOD $[n g / g]$ & Recovery [\%] & $\begin{array}{c}\text { Intra-day [CV \%] } 0.05 \\
\mu \mathrm{g} / \mathrm{g}(5 \mu \mathrm{g} / \mathrm{g})\end{array}$ & $\begin{array}{c}\text { Inter-day [CV \%] } 0.05 \\
\mu \mathrm{g} / \mathrm{g}(5 \mu \mathrm{g} / \mathrm{g})\end{array}$ \\
\hline ATR & $y=8.80 \times 10^{5} x-3.90 \times 10^{5}$ & 0.9999 & 0.03 & $87 \pm 4$ & $6.9(5.3)$ & $7.2(6.0)$ \\
\hline DEDIA & $y=1.50 \times 10^{4} x+4.28 \times 10^{3}$ & 0.9998 & 0.85 & $89 \pm 3$ & $7.3(6.6)$ & $8.0(7.5)$ \\
\hline DEA & $y=3.60 \times 10^{5} x-4.81 \times 10^{4}$ & 0.9998 & 0.04 & $88 \pm 6$ & $5.5(4.1)$ & $5.4(4.2)$ \\
\hline DIA & $y=4.00 \times 10^{5} x+3.9 \times 10^{4}$ & 0.9979 & 0.09 & $95 \pm 5$ & $5.8(4.5)$ & $6.0(5.0)$ \\
\hline HA & $y=1.81 \times 10^{5} x-1.56 \times 10^{4}$ & 0.9998 & 0.05 & $87 \pm 7$ & $6.5(6.8)$ & $6.6(6.5)$ \\
\hline MES & $y=24.57 \times 10^{4} x-11.90 \times 10^{4}$ & 0.9974 & 20 & $89 \pm 9$ & $5.9(5.0)$ & $6.8(5.8)$ \\
\hline AMBA & $y=35.67 \times 10^{4} x-20.44 \times 10^{4}$ & 0.9949 & 5 & $78 \pm 7$ & $5.8(4.2)$ & $7.0(6.6)$ \\
\hline MNBA & $y=22.96 \times 10^{4} x-9.55 \times 10^{4}$ & 0.9991 & 5 & $85 \pm 9$ & $7.9(6.0)$ & $8.7(7.9)$ \\
\hline SUL & $y=9.63 \times 10^{4} x+62.18 \times 10^{4}$ & 0.9989 & 60 & $98 \pm 9$ & $6.7(5.5)$ & $7.0(6.8)$ \\
\hline CMBA & $y=65.12 \times 10^{4} x+74.88 \times 10^{4}$ & 0.9988 & 20 & $91 \pm 12$ & $7.3(4.9)$ & $7.6(7.0)$ \\
\hline \multicolumn{7}{|l|}{ Water } \\
\hline Analyte & Equation & $R^{2}$ & $\mathrm{LOD}[\mu \mathrm{g} / \mathrm{L}]$ & Recovery [\%] & $\begin{array}{c}\text { Intra-day [CV \%] } 10 \\
\mu \mathrm{g} / \mathrm{L}(200 \mu \mathrm{g} / \mathrm{L})\end{array}$ & $\begin{array}{c}\text { Inter-day [CV \%] } 10 \\
\mu \mathrm{g} / \mathrm{L}(200 \mu \mathrm{g} / \mathrm{L})\end{array}$ \\
\hline ATR & $y=1.16 \times 10^{6} x+5.26 \times 10^{6}$ & 0.9998 & 0.35 & $92 \pm 2.1$ & $2.9(1.2)$ & $3.3(1.8)$ \\
\hline DEDIA & $y=1.67 \times 10^{4} x-2.84 \times 10^{4}$ & 0.9995 & 0.61 & $87 \pm 3.2$ & $4.1(3.5)$ & $4.1(3.6)$ \\
\hline DEA & $y=9.24 \times 10^{4} x+5.78 \times 10^{3}$ & 0.9998 & 0.19 & $74 \pm 3.6$ & $2.5(1.4)$ & $2.9(1.7)$ \\
\hline DIA & $y=8.47 \times 10^{5} x-2.48 \times 10^{5}$ & 0.9998 & 0.04 & $84 \pm 5.1$ & $3.1(2.3)$ & $3.8(2.8)$ \\
\hline HA & $y=2.16 \times 10^{5} x-1.05 \times 10^{4}$ & 0.9997 & 0.14 & $86 \pm 4.2$ & $3.8(2.7)$ & $4.0(2.9)$ \\
\hline MES & $y=2.22 \times 10^{6} x+3.26 \times 10^{5}$ & 0.9988 & 0.12 & $87 \pm 3.4$ & $3.0(2.2)$ & $3.8(2.5)$ \\
\hline AMBA & $y=1.11 \times 10^{5} x+3.37 \times 10^{5}$ & 0.9998 & 0.06 & $96 \pm 2.8$ & $3.1(2.3)$ & $3.1(2.5)$ \\
\hline MNBA & $y=4.06 \times 10^{5} x+4.81 \times 10^{5}$ & 0.9999 & 0.15 & $52 \pm 3.0$ & $2.1(2.0)$ & $2.8(2.0)$ \\
\hline SUL & $y=3.64 \times 10^{6} x+1.26 \times 10^{3}$ & 0.9997 & 0.20 & $80 \pm 2.7$ & $1.9(1.5)$ & $2.1(1.5)$ \\
\hline CMBA & $y=3.81 \times 10^{6} x+2.88 \times 10^{4}$ & 0.9998 & 0.26 & $76 \pm 3.5$ & $3.2(2.7)$ & $3.8(2.2)$ \\
\hline
\end{tabular}

$n=9, \mu=0.05$; analytical wavelength: ATR, DEDIA, DEA, DIA: $220 \mathrm{~nm}$; HA: 240 nm; MES: 230 nm; AMBA: 225 nm; MNBA: 222 nm; SUL: $240 \mathrm{~nm}$; CMBA: $222 \mathrm{~nm}$

\section{Results}

Among all investigated herbicides and their degradation products, two degradation products of ATR, HA and DIA; and one degradation product of SUL, CMBA, were detected in sediment samples. The concentration of HA and CMBA correlated to the $\mathrm{OC}$ and $\mathrm{pH}$ of particular sediments were presented in Fig. 2 The concentration of DIA was $1.1 \mu \mathrm{g} / \mathrm{g}$.
In the collected soil samples, atrazine degradation products DEA and DIA, as well as SUL and its degradation product CMBA were found. The results of DEA, SUL and CMBA determination in soil samples are presented in Fig. 3. DIA was determined in four samples in the concentration range of $0.04-1.64 \mu \mathrm{g} / \mathrm{g}$.

The results of atrazine, triketones and their degradation products determination in collected surface water samples were presented in Fig. 4. 
A

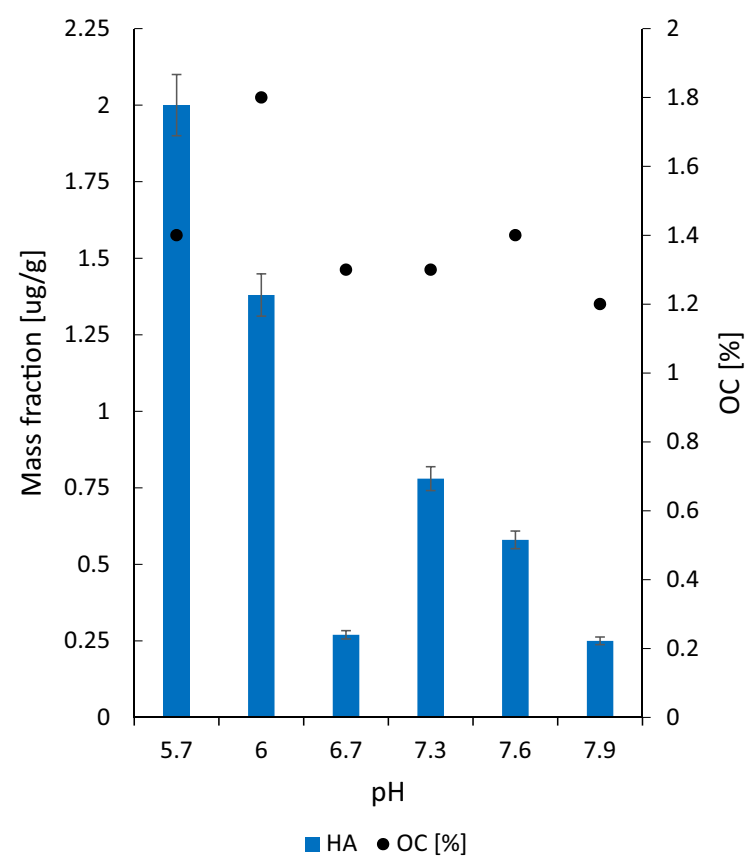

B

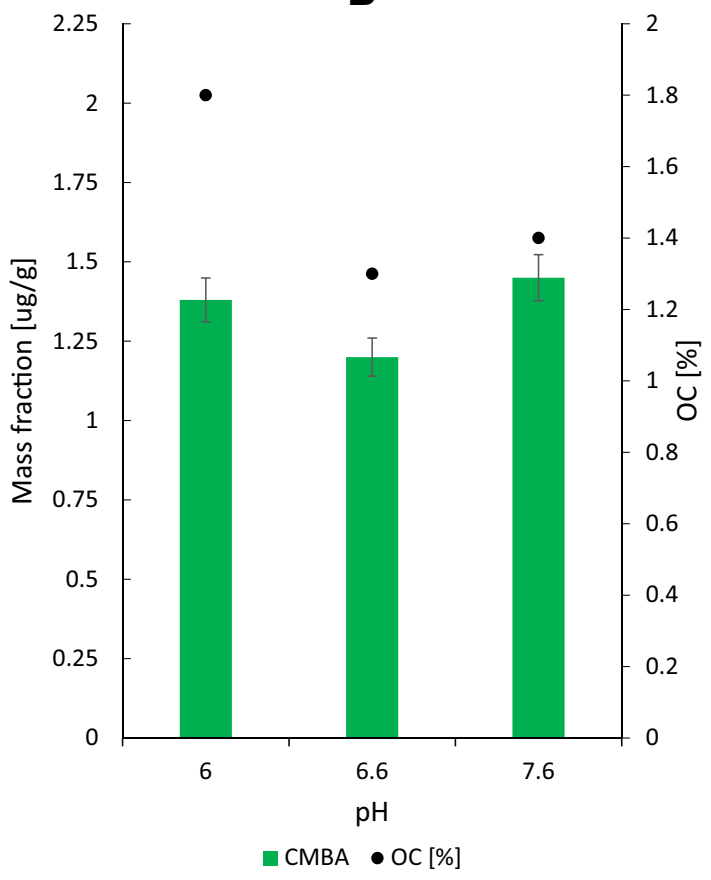

Sediment samples were divided into five groups according to the area where they were collected:

1. Forest

2. Cultivations

3. Meadow

4. Industrial area

5. Other

Such grouping of sediment samples allowed verifying the thesis, that the area from which samples were collected had an influence on the analysed variables. For this purpose, a oneway analysis of variance was applied. Fig. 6c shows the differences in $\mathrm{pH}$ of sediment samples depending on the type of sampling area.

Based on $p$ value, it was concluded, that the difference between average $\mathrm{pH}$ for studied groups is statistically significant $-(p$ value $=0.003)$, what is presented in Table 4$)$.

The differences in OC in samples from different sampling areas were not statistically different, as is presented in Fig. 6d and in Table 4.

Chemometric analysis was also applied to the results obtained from the soil samples. In neither of the studied cases was a statistically significant relationship between the concentrations of examined herbicides, their degradation products and soil parameters $(\mathrm{OC}, \mathrm{pH})$ was observed. The $p$ values were as follows:

- $\quad p$ value $\mathrm{pH}=0.2373$

- $\quad p$ value_OC $=0.3439$ 
A

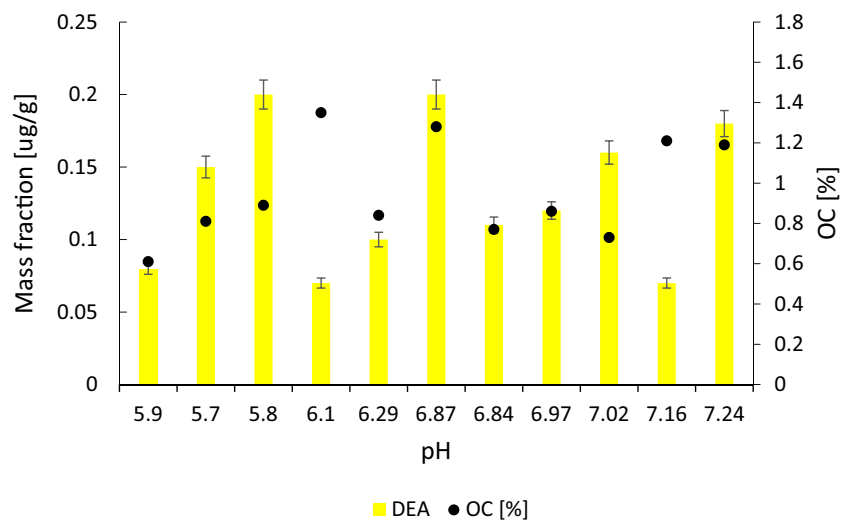

B

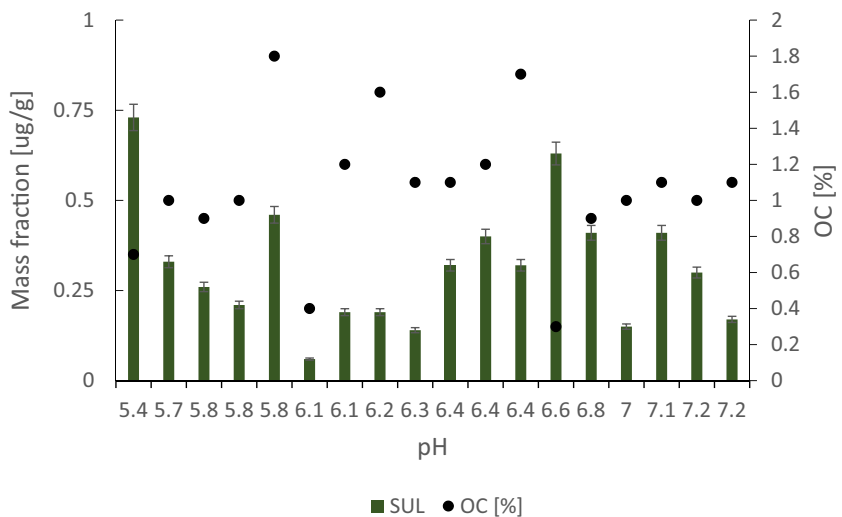

C

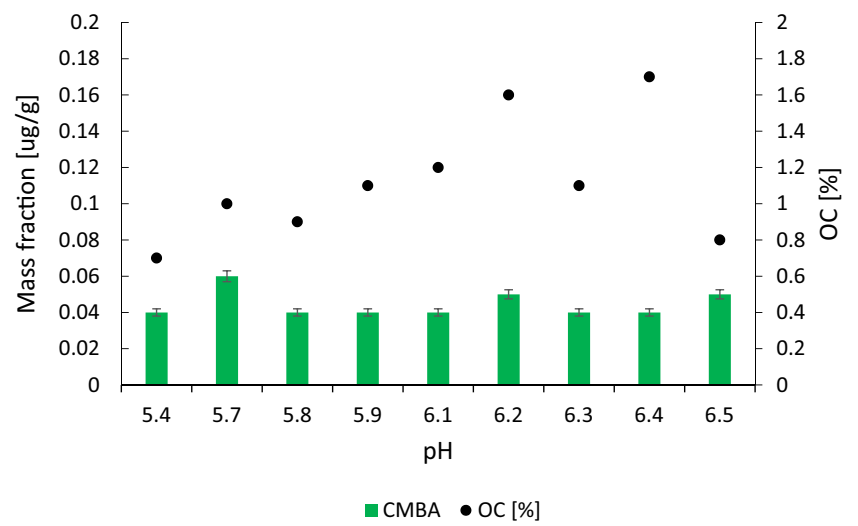

Fig. 3 Concentration of DEA (a), SUL (b) and CMBA (c) in soil samples

- $\quad p$ value_ATR $=0.3535$

- $p$ value_MES $=0.5855$

- $p$ value_SUL $=0.2327$

\section{Discussion}

\section{Triazines}

Stability of triazines and their degradation products has attracted scientific attention because these compounds are present in environment after over 10 years after the withdrawal from the use (Garbin et al. 2007; Prosen et al. 2007; Hutta et al. 2011; Li et al. 2012). This is the consequence of the longterm transfer of residues from agricultural areas where these herbicides were previously used.

Atrazine fate in the environment, e.g. sorption, leaching and degradation depends, inter alia, on soil characteristics as well as environmental conditions; therefore, the prediction of their stability is a difficult task.

FTIR, differential thermal analysis (DTA) and ${ }^{1} \mathrm{H}-\mathrm{NMR}$ studies on interactions between atrazine and other s-triazine compounds with humic substances suggested the occurrence of H-bonds, possibly involving carbonyl groups of humic acids and secondary amine groups of the s-triazine. It was found that the adsorption capacity for the s-triazines is related to humic substances content and titratable acidity of the soil (Nearpass 1976). It was inferred that adsorption occurred by $\mathrm{H}$-bonding between the amino protons of the triazine ring and humic acids. The positive correlation between the $K_{\mathrm{oc}}$ and octanol-water partition coefficient values may implicate that although hydrogen-bonding is important in triazine-soil organic matter interactions (SOM), this type of complexation is probably governed by hydrophobic partitioning-like interactions. Similar conclusions were reached by Kulikova and Perminova (2002). According to their investigations, triazinic compounds are sorbed by sorbents containing a high level of aromatic structures, therefore, hydrophobic bonding is responsible for the interactions of these compounds with soil organic matter. On the other hand, Chefetz (2003; Chefetz et al. 2004), and Salloum et al. (2002; Alletto et al. 2010) claimed, that atrazine exhibits also affinity to aliphatic domains of soil organic matter.

ATR was not detected in the sediment, soil or water samples. Since it has not been used for many years, it is degraded 

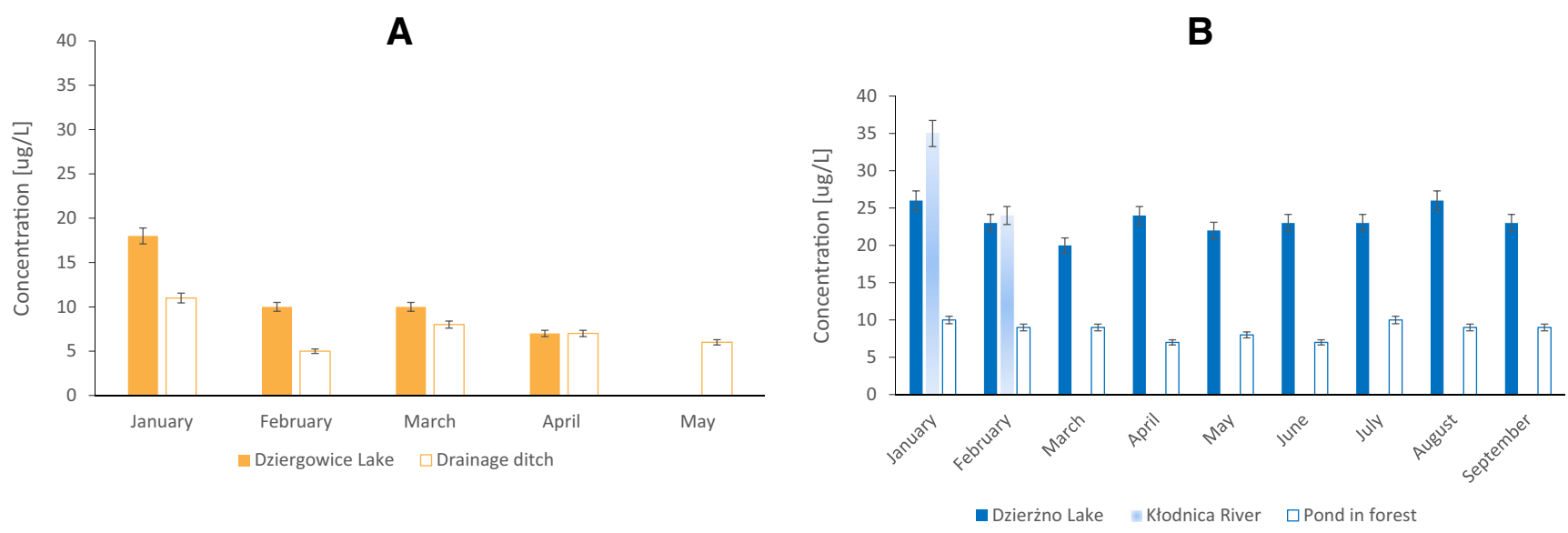

C

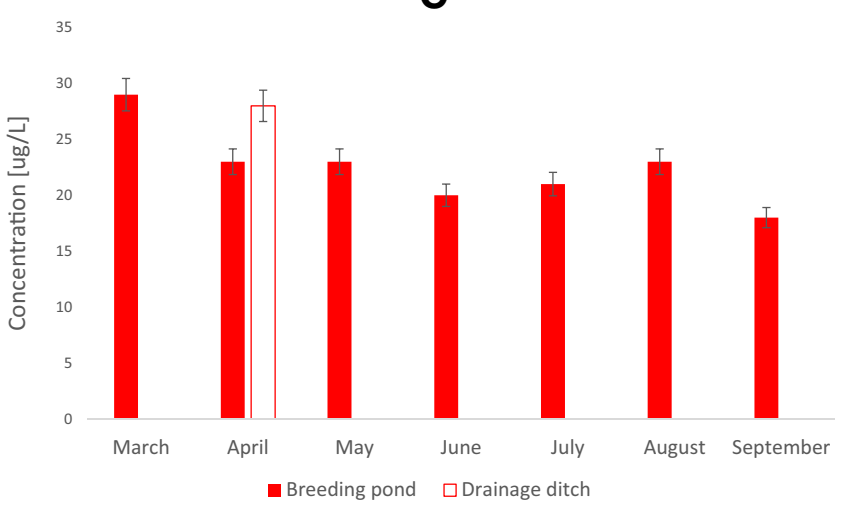

Fig. 4 The concentration of DIA (a), HA (b) and AMBA (c) in surface water samples

in the environment, and its concentration is below limit of quantification (LOQ) of the applied analytical method. However, other researchers (i.e. Farlin et al. 2013, Geng et al. 2013) detected ATR in soil samples at concentrations up to $11.1 \mu \mathrm{g} / \mathrm{kg}$. Since the stability of pesticides is strongly influenced by soil texture, organic matter content and type and activity of microorganisms, the direct comparison of this type research obtained by different research groups is difficult.
DEA was detected in 11 soil samples (sample nos. 21, 22, $24,26-29,30,31,33,34)$ in the concentration range of $0.07-$ $0.18 \mu \mathrm{g} / \mathrm{g}$ (Fig. 2). No relationship between the concentration of this compound and soil $\mathrm{pH}$ nor OC was observed. In soils that are characterized by low $\mathrm{pH}$, strong interaction between DEA and soil occurs that hinder this pesticide's elution by surface water and its migration to sediments. Therefore, the absence of DEA in sediment and water samples was observed.

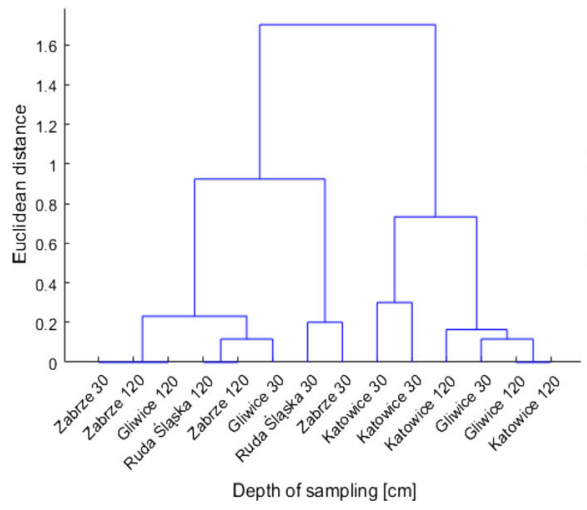

A

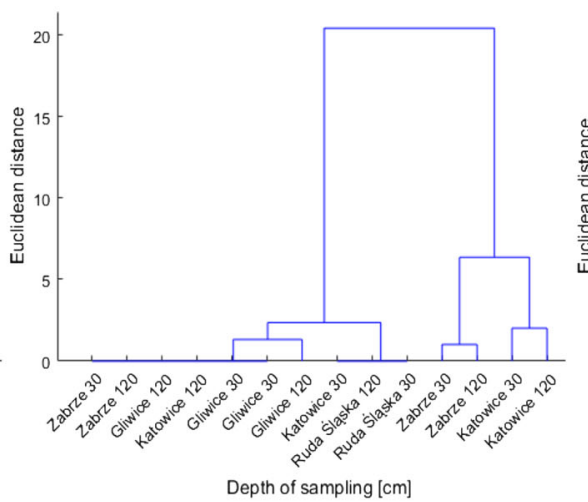

B

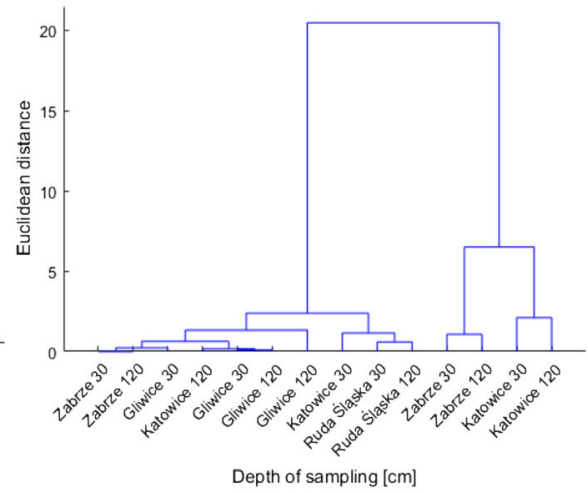

C

Fig. 5 Dendrograms of $\mathrm{pH}(\mathbf{a})$, OC content (b) and for OC content and $\mathrm{pH}(\mathbf{c})$ of sediments samples collected at 30- and 120-cm depth 

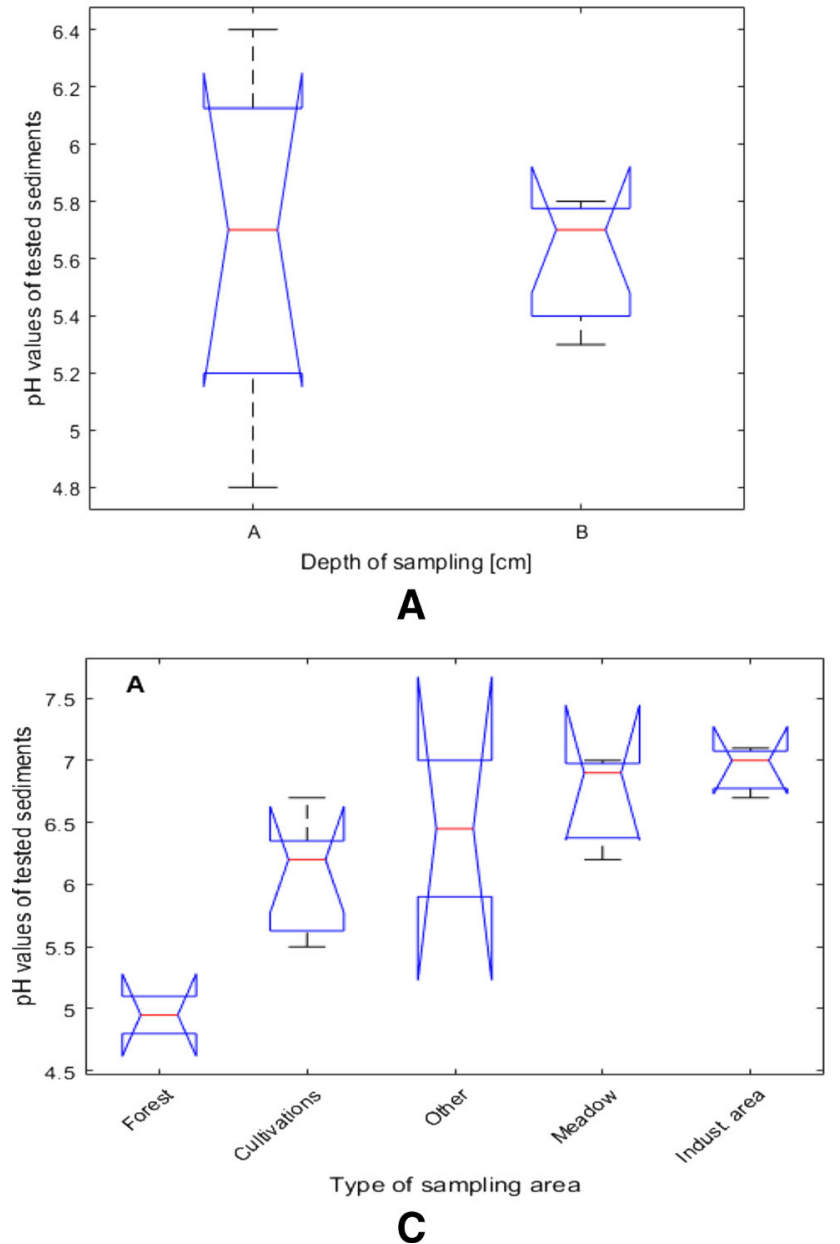

Fig. 6 Diagram of between-groups variation for $\mathrm{pH}$ values (a) and OC content (b) of sediment samples. Diagram of between-groups variation of $\mathrm{pH}$ values in sediment samples depending on the type of sampling area

DIA was detected in sediment from river Bobrówka (sample no. 12) at a concentration of $1.1 \mu \mathrm{g} / \mathrm{g}(\mathrm{SD}=0.1 \mu \mathrm{g} / \mathrm{g})$ and soil samples from Szczekociny I (sample no. 28), Sucha Beskidzka (sample no. 22), Tychy Wilkowyje II (no. 26), and Rudziniec (no. 39) in the range of 0.04-1.64 $\mu \mathrm{g} / \mathrm{g}$.

The presence of DIA in the surface water from the drainage ditch in Rudziniec was the result of its presence in the soil (sample no. 39, DIA concentration $1.50(\mathrm{SD}=0.25) \mu \mathrm{g} / \mathrm{g}$ ) from the same location. This compound was transported to surface water with atmospheric precipitation; therefore, its concentration was strictly related to rainfall, snowfall and its thaw. DIA concentration in water from this location varied form 5 to $11 \mu \mathrm{g} / \mathrm{L}$ in the period January-June. In July and August, it was also detected; however, its concentration was below limit of quantification (LOQ), due to scanty rainfall. DIA was also detected in water from Dziergowice Lake in the concentration range of $7-18 \mu \mathrm{g} / \mathrm{L}$ in the period January-April.

Caquet et al. (2013) reported both DEA and DIA presence in estuarine continuums in the Bay of Vilaine area (France). However, the concentration of these compounds was

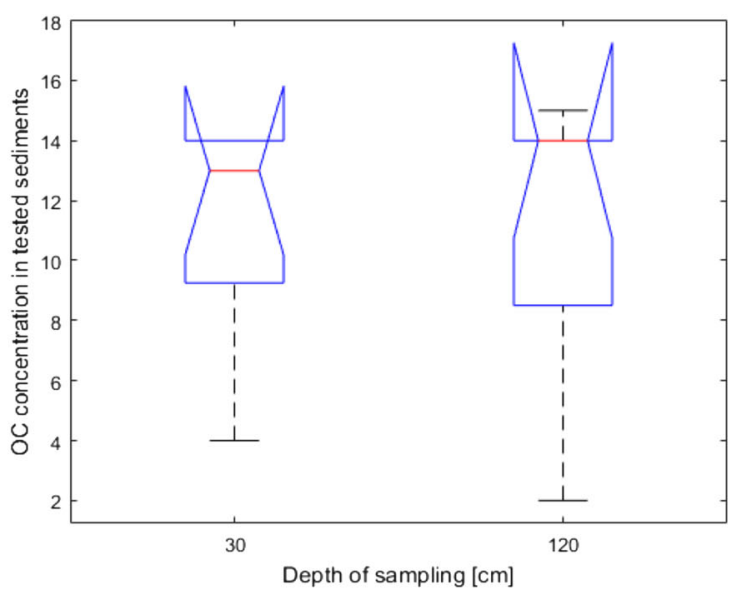

B

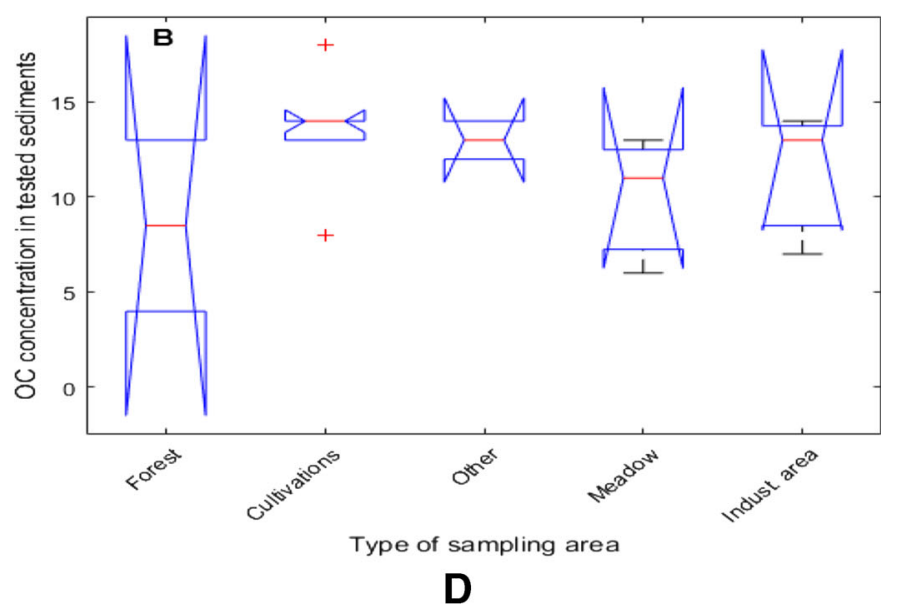

(c). Diagram of between-groups variation of OC content in sediments depending on sampling area (d)

significantly lower than in the present report $(0.89$ and $0.55 \mu \mathrm{g} / \mathrm{L}$ for DEA and DIA, respectively). This discrepancy was caused by different place of sampling: agricultural area versus estuary area, where the concentration of pesticides is lower because of a much larger mass of water in comparison to local streams and local lakes. Moreover, in France atrazine is forbidden since 2003, whereas in Poland since 2008.

HA was determined in six sediment samples (sample nos. $2,11,12,14,16,17)$, its concentration was in the range of $0.25-2.00 \mu \mathrm{g} / \mathrm{g}$. HA was detected in ten soil samples; however, its concentration was below the LOQ of the applied analytical method. The presence of HA in sediment samples was caused by its relatively low water solubility and the longest half-life among all investigated triazine compounds (Table 1); therefore, it accumulated in sediment. It should be noted that HA was detected in regions where mainly maize has been cultivated and in the vicinity of a water treatment plant. The results indicated the high stability of this ATR degradation product and its tendency to accumulate in sediments, as well as its persistence in the processes of water purification. 
Table 4 ANOVA table

\begin{tabular}{llllll}
\hline Source & SS & Df & MS & $F$ & Prob $>F$ \\
\hline
\end{tabular}

Table for $\mathrm{pH}$ values of sediment samples

\begin{tabular}{lcccll} 
Groups & 0.018 & 1 & 0.018 & 0.095 & 0.763 \\
Error & 2.246 & 12 & 0.187 & - & - \\
Total & 2.264 & 13 & - & - & - \\
\multicolumn{5}{l}{ Table for } \\
Groups & 0.071 & 1 & 0.071 & 0 & 0.953 \\
Error & 235.143 & 12 & 19.595 & - & - \\
Total & 235.214 & 13 & - & - & - \\
Table for & pH & values in sediment samples & & \\
Groups & 1.958 & 7 & 0.280 & 5.5 & 0.027 \\
Error & 0.305 & 6 & 0.051 & - & - \\
Total & 2.264 & 13 & - & - & -
\end{tabular}

Table for OC content in sediment samples depending on type of sampling area

\begin{tabular}{lrrrll} 
Groups & 53.590 & 4 & 13.397 & 1.080 & 0.409 \\
Error & 148.881 & 12 & 12.407 & - & - \\
Total & 202.471 & 16 & - & - & - \\
\hline
\end{tabular}

source the source of the variability; $S S$ the sum of squares due to each source; $d f$ the degrees of freedom associated with each source; $N$ the total number of observation; $k$ the number of groups; $N-k$ within-groups degrees of freedom (error), $k-1$ the between-groups degrees of freedom (columns); $N$ the total degrees of freedom. $N-1=(N-k)+(k-1) ; M S$ the mean squares for each source, which is the ratio SS/df; $F F$ statistic, which is the ratio of the mean squares; $\operatorname{Prob}>F$ the $p$ value, which is the probability that the $F$ statistic can take a value larger than the computed test-statistic value. ANOVA derives this probability from the cumulative distribution function of $F$ distribution; Groups variability due to the differences among the group means (variability between groups); Error variability due to the differences between the data in each group and the group mean (variability within groups); Total total variability

Moreover, a negative correlation between the HA content and sediment $\mathrm{pH}$ was observed. Probably, HA sorbed stronger on the mineral components of soil, rather than on organic matter. HA was detected in water samples collected form Dzierżno Lake, Kłodnica River and a pond surrounded by forest. Its concentration in the stagnant water reservoir was stable during the entire experimental period, and was in the range of 20-26 and $7-10 \mu \mathrm{g} / \mathrm{L}$ from water from Dzierżno Lake and a pond in a forest, respectively. HA was determined in water from Kłodnica River only in January and February (concentration range $24-35 \mu \mathrm{g} / \mathrm{L}$ ). In the remaining months, it was also detected but its concentration was below the LOQ.

Geng et al. (2013) determined ATR and its degradation products in soil and water samples collected in one of the agricultural area in China, where atrazine is still used. According to their studies, the mean concentration of ATR was $106.8 \mathrm{ng} / \mathrm{L}$ and $11.1 \mu \mathrm{g} / \mathrm{kg}$; DEA was $0.9 \mathrm{ng} / \mathrm{L}$ and $0.4 \mu \mathrm{g} / \mathrm{kg}$ and HA was $0.3 \mathrm{ng} / \mathrm{L}$ and $7.8 \mu \mathrm{g} / \mathrm{kg}$ for soil and water samples, respectively. The comparison of these results with the results presented in this work indicates a gradual decrease in the concentrations of atrazine and its derivatives, in the regions in which it was withdrawn from use. However, this loss is not for each compound the same. This is due to the complex degraded processes in the environment.

\section{Triketones}

In the collected soil and sediment samples neither MES nor its degradation products were detected, since these compounds are well-soluble in water. Moreover, AMBA and MNBA are characterized by the shortest half-life in soil among all investigated triketone by-products (Table 1).

CMBA, the degradation product of SUL, was determined in sediment samples. It was present in three samples $(3 ; 12$; 16 ), in the concentration range of $1.20-1.45 \mu \mathrm{g} / \mathrm{g}$. These samples were collected in the vicinity of maize cultivation and water treatment plants.

In case of sample nos. 2 and 3, where HA and CMBA were detected, respectively, both analytes were present in the upper layer of the sediment. It may suggest that these compounds are strongly bound to the sediment particles that preclude their migration into deeper layers of sediment.

SUL was determined in 18 soil samples $(18-20 ; 22-25 ; 27-$ $30 ; 34-40)$ in the concentration range of $0.06-0.73 \mu \mathrm{g} / \mathrm{g}$. No correlation between OC nor $\mathrm{pH}$ and SUL content in soil was observed. CMBA, the SUL degradation product, was determined in nine soil samples $(18 ; 22 ; 24 ; 27-29 ; 37 ; 38 ; 40)$ in the concentration range of $0.04-0.06 \mu \mathrm{g} / \mathrm{g}$. CMBA coexisted with SUL, but only in samples that $\mathrm{pH}$ was below 6.5. SUL was determined in soil samples collected from the maize and potatoes cultivation (that is applied as a crop rotation with maize).

SUL and CMBA were determined in water from Kłodnica River, but only in March - the month of intense agrotechnical intervention. Their concentration was high $(57$ and $143 \mu \mathrm{g} / \mathrm{L}$, for SUL and CMBA, respectively), however, transient.

AMBA, MES degradation product, was determined in water collected from the breeding pond. The maximum concentration of AMBA $(29 \mu \mathrm{g} / \mathrm{L})$ was determined in March, and then it was slowly decreased to $18 \mu \mathrm{g} / \mathrm{L}$ at 6 months. This slow decrease in the AMBA concentration was due to the slow exchange of water between the pond and its tributaries and the highest stability of this compound in environment among all investigated triketones and their degradation products (Table 1; Barchanska et al. 2016). MNBA was determined in water from the drainage ditch at a concentration of $147 \mu \mathrm{g} / \mathrm{L}$ (sample collected in April).

The obtained data could not be compared with regulatory AA-EQS and MAC-EQS for priority substances, because triketones and their degradation products and ATR degradation products are not included in these regulations (EU 2008). However, on the basis of the presented study, the concentration of triketone herbicides and their metabolites as well as ATR degradation products should be monitored, due to their stability in the environment. 


\section{Conclusion}

Seven years after the withdrawal from use in Poland, ATR was not detected in any of the collected samples. However, its degradation products are still present in environment.

Forty-one percent of sediment, $71 \%$ of soil and $8 \%$ of surface water samples contained these compounds. DIA was the most common ATR degradation product found. It was determined in soil $(0.04-1.62 \mu \mathrm{g} / \mathrm{g})$, sediment $(1.1 \mu \mathrm{g} / \mathrm{g})$ and water $(5-18 \mu \mathrm{g} / \mathrm{L})$ samples.

Among triketone herbicides, SUL was the most common compound found, and it was determined in $85 \%$ of soil samples $(0.06-0.73 \mu \mathrm{g} / \mathrm{g})$; its degradation product (CMBA) was present in $43 \%$ of soil samples and in $17 \%$ of sediment samples. Sediments and soil samples were free of MES and its degradation products.

MNBA and AMBA as well as SUL and CMBA were detected occasionally in surface water samples. Although their concentration was high (up to $147 \mu \mathrm{g} / \mathrm{L}$ for MNBA), it was transient, highly influenced by rainfalls.

The results obtained for triketones may be indicative of their rapid degradation in environment. A statistically significant relationship was not found between the concentrations of examined herbicides, their degradation products and soil parameters $(\mathrm{OC}, \mathrm{pH})$.

The half-life of herbicides in the environment given by the producers of agrochemicals does not always correspond to their actual persistence in the environment. Pesticide stability in the environment is influenced by many factors (temperature, composition and $\mathrm{pH}$ of soil (sediment), type and activity of microorganisms, etc.) that are difficult to predict under experimental conditions.

Open Access This article is distributed under the terms of the Creative Commons Attribution 4.0 International License (http:// creativecommons.org/licenses/by/4.0/), which permits unrestricted use, distribution, and reproduction in any medium, provided you give appropriate credit to the original author(s) and the source, provide a link to the Creative Commons license, and indicate if changes were made.

\section{References}

Alekseeva T, Kolyagin Y, Sancelme M, Besse-Hoggan P (2014) Effect of soil properties on pure and formulated mesotrione adsorption onto vertisol (Limagne plane, Puy-de-Dôme, France. Chemosphere 111: 177-183. doi:10.1016/j.chemosphere.2014.03.061

Alferness P, Wiebe L (2002) Determination of mesotrione residues and metabolites in crops, soil, and water by liquid chromatography with fluorescence detection. J Agric Food Chem 50:3926-3934. doi:10.1021/jf011696y
Alletto L, Coquet Y, Benoit P, Heddadj D, Barriuso E (2010) Tillage management effects on pesticide fate in soils. A review. Agron Sustain Develop 30:367-400. doi:10.1051/agro/2009018

Baranda A, de Marañón IM, Barranco A (2012) Fast atrazine photodegradation in water by pulsed light technology. Wat Res 46 : 669-678. doi:10.1016/j.watres.2011.11.034

Barchanska H, Rusek M, Szatkowska A (2012) New procedures for simultaneous determination of mesotrione and atrazine in water and soil. Comparison of the degradation processes of mesotrione and atrazine. Environ Monit Assess 184:321-334. doi:10.1007/s10661-011-1970-5

Barchanska H, Kowalska A, Poloczek B (2014) Extraction procedures for the study of phytotoxicity and degradation processes of selected triketones in a water ecosystem. Environ Sci Pollut Res 21:47514758. doi:10.1007/s11356-013-2425-Z

Barchanska H, Kluza A, Krajczewska K, Maj J (2016) Degradation study of mesotrione and other triketone herbicides on soils and sediments. J Soils Sediments 16:125-133. doi:10.1007/s11368-015-1188-1 in press

Bardot C, Besse-Hoggan P, Carles L, Le Gall M, Clary G, Chafey P, Federici C, Broussard C, Batisson I (2015) How the edaphic Bacillus megaterium strain Mes11 adapts its metabolism to the herbicide mesotrione pressure. Environ Pollut 199:198-208. doi:10.1016/j.envpol.2015.01.029

Batisson I, Crouzet O, Besse-Hoggan P, Sancelme M, Mangot J-F, Mallet C, Bohatier J (2009) Isolation and characterization of mesotrionedegrading bacillus sp. from soil. Environ Pollut 157:1195-1201. doi:10.1016/j.envpol.2008.12.009

Bonnet J-L, Bonnemoy F, Dusser M, Bohatier J (2008) Toxicity assessment of the herbicides sulcotrione and mesotrione toward two reference environmental microorganisms: Tetrahymena pyriformis and Vibrio fischeri. Arch Environ Contam Toxicol 55:576-583. doi:10.1007/s00244-008-9145-2

Calvayrac C, Martin-Laurent F, Faveaux A, Picault N, Panaud O, Coste C-M, Chaabane H, Cooper J-F (2012) Isolation and characterisation of a bacterial strain degrading the herbicide sulcotrione from an agricultural soil. Pest Manag Sci 68:340-347. doi:10.1002 /ps. 2263

Caquet T, Roucaute M, Mazzella N, Delmas F, Madigou C, Farcy E, Burgeot T, Allenou J-P, Gabellec R (2013) Risk assessment of herbicides and booster biocides along estuarine continuums in the bay of Vilaine area (Brittany, France. Environ Sci Pollut Res 20:651666. doi:10.1007/s11356-012-1171-y

Chaabane H, Vulliet E, Calvayrac C, Coste C-M, Cooper J-F (2008) Behaviour of sulcotrione and mesotrione in two soils. Pest Manag Sci 64:86-93. doi:10.1002/ps.1456

Chefetz B (2003) Sorption of phenanthrene and atrazine by plant cuticular fractions. Environ Toxicol Chem 22:2492-2498. doi:10.1897 /02-461

Chefetz B, Bilkis YI, Polubesova T (2004) Sorption-desorption behavior of triazine and phenylurea herbicides in Kishon river sediments. Water Res 38:4383-4394. doi:10.1016/j. watres.2004.08.023

Cheng M, Zeng G, Huang D, Lai C, Xua P, Zhang C, Liu Y, Wan J, Gong X, Zhua Y (2016) Degradation of atrazine by a novel Fenton-like process and assessment the influence on the treated soil. J Haz Mat 312:184-191. doi:10.1016/j.jhazmat.2016.03.033 0304-3894

Crouzet O, Batisson I, Besse-Hoggan P, Bonnemoy F, Bardot C, Poly F et al (2010) Response of soil microbial communities to the herbicide mesotrione: a dose-effect microcosm approach. Soil Biol Biochem 42:193-202. doi:10.1016/j.soilbio.2009.10.016

Crouzet O, Wiszniowski J, Donnadieu F, Bonnemoy F, Bohatier J, Mallet C (2013) Dose-dependent effects of the herbicide mesotrione on soil cyanobacterial communities. Arch Environ Contam Toxicol 64:2331. doi:10.1007/s00244-012-9809-9 
Dyson JS, Beulke S, Brown CD, Lane MCG (2002) Adsorption and degradation of the weak acid mesotrione in soil and environmental fate implications. Organic compounds in the environment. J Environ Qual 31:613-618. doi:10.2134/jeq2002.0613

European Union (2000) Directive 2000/60/EC of the European Parliament and of the council of 23 October 2000 establishing a framework for the community action in the field of water policy (water framework directive). Off J Eur Comm Ser L327:1-73

European Union (2008) Directive 2008/105/EC of the European Parliament and of the Council of 16 December 2008 on environmental quality standards in the field of water policy, amending and subsequently repealing Council Directives 82/176/EEC, 83/513/ EEC, 84/156/EEC, 84/ 491/EEC, 86/280/EEC and amending Directive 2000/60/EC of the European Parliament and of the Council. Official Journal of the European Union L 384/84. Available at http://eur-lex.europa.eu/LexUriServ/LexUriServ. do?uri0OJ:L:2008:348:0084:0097:EN:PDF. Accessed on 9 October 2015

European Union (2009) Directive 2009/128/EC of the European Parliament and of the council of 21 October 2009 establishing a framework for the community action to achieve sustainable use of pesticides. Off J Eur Comm Ser L309:71-86

Farlin J, Gallé T, Bayerle M, Pittois D, Braun C, El Khabbaz H, Lallement C, Leopold U, Vanderborght J, Weihermueller L (2013) Using the long-term memory effect of pesticide and metabolite soil residues to estimate field degradation half-life and test leaching predictions. Geoderma 207:15-24. doi:10.1016/j.geoderma.2013.04.028

Freitas LG, Gotz CW, Ruff M, Singer HP, Mueller SR (2004) Quantification of the new triketone herbicides, sulcotrione and mesotrione, and other important herbicides and metabolites, at the $\mathrm{ng} / \mathrm{l}$ level in surface waters using liquid chromatography tandem mass spectrometry. J Chromatogr A 1028:277-286. doi:10.1016/j. chroma.2003.11.09

Garbin JR, Milori DMBP, Simoes ML, da Silva WTL, Neto LM (2007) Influence of humic substances on the photolysis of aqueous pesticide residue. Chemosphere 66:1692-1698. doi:10.1016/j. chemosphere.2006.07.017

Geng Y, Ma J, Jia R, Xue L-q, Tao C-j, Li C-j, Ma X, Lin Y (2013) Impact of long-term atrazine use on groundwater safety in Jilin Province. China J Integr Agric 12:305-313. doi:10.1016/S2095-3119(13)60229-4

Ghanem A, Bados P, Perreau F, Benabdallah R, Plagellat C, de Alencastro LF, Einhorn J (2008) Multiresidue analysis of atrazine, diuron and their degradation products in sewage sludge by liquid chromatography tandem mass spectrometry. Anal Bioanal Chem 391:345-352. doi:10.1007/s00216-008-2007-y

Goujon E, Sta C, Trivella A, Goupil P, Richard C, Ledoigt G (2014) Genotoxicity of sulcotrione pesticide and photoproducts on Allium cepa root merystem. Pest Biochem Phys 113:47-54. doi:10.1016/j. pestbp.2014.06.002

Hase Y, Tatsuno M, Nishi T, Kataoka K, Kabe Y, Yamaguchi Y, Ozawa N, Natori M, Handa H, Watanabe H (2008) Atrazine binds to F1F0ATP synthase and inhibits mitochondrial function in sperm Biochem. Biophys Res Comm 366:66-72. doi:10.1016/j. bbrc.2007.11.107

$\mathrm{Hu}$ E, Cheng H (2013) Rapid extraction and determination of atrazine and its degradation products from microporous mineral sorbents using microwave-assisted solvent extraction followed by ultra-HPLC-MS/ MS. Microchim Acta 180:703-710. doi:10.1007/s00604-013-0971-1

Hutta R, Góra R, Halko R, Chalanyova M (2011) Some theoretical and practical aspects in the separation of humic substances by combined liquid chromatography methods. J Chromatogr A 1218:8946-8957. doi:10.1016/j.chroma.2011.06.107

ISO 10381-4:2003 (2003) Soil quality-sampling-part 4: guidance on the procedure for investigation of natural, near-natural and cultivated sites
ISO 5667-15:2009 (2009) Water quality-sampling-part 15: guidance on the preservation and handling of sludge and sediment samples

Ji Y, Dong C, Kong D, Lu J (2015) New insights into atrazine degradation by cobalt catalyzed peroxymonosulfate oxidation: kinetics, reaction products and transformation mechanisms. J Haz Mat 285:491-500. doi:10.1016/j.jhazmat.2014.12.026

Joly P, Bonnemoy F, Charvy J-C, Bohatier J, Mallet C (2013) Toxicity assessment of the maize herbicides S-metolachlor, benoxacor, mesotrione and nicosulfuron, and their corresponding commercial formulations, alone and in mixtures, using the Microtox test. Chemosphere 93:2444-2450. doi:10.1016/j.chemosphere. 2013.08.074

Jović M, Manojlović D, Stanković D, Dojcinović B, Obradović B, Gasić D, Roglić G (2013) Degradation of triketone herbicides, mesotrione and sulcotrione, using advanced oxidation processes. J Haz Mat 260:1092-1099. doi:10.1016/j.jhazmat.2013. 06.073

Kulikova NA, Perminova IV (2002) Binding of atrazine to humic substances from soil, peat, and coal related to their structure. Environ Sci Technol 36:3720-3724. doi:10.1021/es015778e

Lekkerkerker-Teunissen K, Benotti MJ, Snyder SA, van Dijk HC (2012) Transformation of atrazine, carbamazepine, diclofenac and sulfamethoxazole by low and medium pressure UV and $\mathrm{UV} / \mathrm{H} 2 \mathrm{O} 2$ treatment. Sep Pur Technol 96:33-43. doi:10.1016/j. seppur.2012.04.018

Li X, Wu T, Huang H, Zhang S (2012) Atrazine accumulation and toxic responses in maize Zea mays. J Environ Sci 24:203-208. doi:10.1016/S1001-0742(11)60718-3

Moschet C, Wittmer I, Simovic J, Junghans M, Piazzoli A, Singer H, Stamm C, Leu C, Hollender J (2014) How a complete pesticide screening changes the assessment of surface water quality. Environ Sci Technol 48:5423-5432. doi:10.1021/es500371t

Mou RX, Chen MX, Cao ZY, Zhu ZW (2011) Simultaneous determination of triazine herbicides in rice by high-performance liquid chromatography coupled with high resolution and high mass accuracy hybrid linear ion trap-orbitrap mass spectrometry. Anal Chim Acta 76:149-156. doi:10.1016/j.aca.2011. 08.030

Nachimuthu G, Halpin NV, Bell MJ (2016) Effect of sugarcane cropping systems on herbicide losses in surface runoff. Sci Total Environ 557558:773-784. doi:10.1016/j.scitotenv.2016.03.105

Nearpass DC (1976) Adsorption of picloram by humic acids and humans. Soil Sci 121:272-277

Ouyang W, Huang W, Wei P, Hao F, Yu Y (2016a) Optimization of typical diffuse herbicide pollution control by soil amendment configurations under four levels of rainfall intensities. J Environ Manag 175:1-8. doi:10.1016/j.jenvman.2016.03.026

Ouyang W, Zhao X, Tysklind M, Hao F (2016b) Typical agricultural diffuse herbicide sorption with agricultural waste derived biochars amended soil of high organic matter content. Water Res 9:156-163. doi:10.1016/j.watres.2016.01.055 0043-1354

Owens DK, Nanayakkara NPD, Dayan FE (2013) In planta mechanism of action of leptospermone: impact of its physico-chemical properties on uptake, translocation, and metabolism. J Chem Ecol 39:262270. doi:10.1007/s10886-013-0237-8

PN-ISO 10390: 2007 Jakość gleby-Oznaczanie pH

PN-ISO 14235: 1997 Oznaczanie zawartości węgla organicznego przez utlenienie dichromianem(VI) w środowisku kwasu siarkowego(VI)

PN-ISO 5667-4: 2003 Jakość wody - Pobieranie próbek - Cześćc 4: Wytyczne dotyczące pobierania próbek z jezior naturalnych i sztucznych zbiorników zaporowych

PN-ISO 5667-6: 2003 Jakość wody - Pobieranie próbek - Część 6: Wytyczne dotyczące pobierania próbek z rzek i strumieni

Prado B, Duwig C, Hidalgo C, Müller K, Mora L, Raymundo E, Etchevers JD (2014) Transport, sorption and degradation of atrazine 
in two clay soils from Mexico: andosol and vertisol. Geoderma 232234:628-639. doi:10.1016/j.geoderma.2014.06.011

Price RG, Baranowska I, Griffith HMT, Abuknesha RA, Barchanska H (2006) Analysis of herbicides: demonstration of the utility of enzyme immunoassay verification by HPLC. Biomarkers 11:291305. doi:10.1080/13547500600625729

Prosen H, Fingler S, Zupancic-Kralj L, Drevenkar V (2007) Partitioning of selected environmental pollutants into organic matter as determined by solid-phase microextraction. Chemosphere 66:580 1589. doi:10.1016/j.chemosphere.2006.08.006

Rocaboy-Faquet E, Noguer T, Romdhane S, Bertrand C, Dayan FE, Barthelmebs L (2014) Novel bacterial bioassay for a high-throughput screening of 4-hydroxyphenylpyruvate dioxygenase inhibitors. Appl Microbiol Biotechnol 98:72437252. doi:10.1007/s00253-014-5793-5

Roustan A, Aye M, De Meo M, Di Giorgio C (2014) Genotoxicity of mixtures of glyphosate and atrazine and their environmental transformation products before and after photoactivation. Chemosphere 108:93-100. doi:10.1016/j.chemosphere.2014.02.07

Salloum M, Chefetz B, Hatcher P (2002) Phenanthrene sorption by aliphatic-rich natural organic matter. Environ Sci Technol 36: 1953-1958. doi:10.1021/es015796w
Ter Halle A, Wiszniowski J, Hitmi A, Ledoigt G, Bonnemoy F, Bonnet JL (2009) Photolysis of the herbicide sulcotrione: formation of a major photoproduct and its toxicity evaluation. Pest Manag Sci 65:14-18. doi:10.1002/ps.1637

Trivella A, Stawinoga M, Dayan FE, Cantrell CL, Mazellier P, Richard C (2015) Photolysis of natural b-triketonic herbicides in water. Wat Res 78:28-36. doi:10.1016/j.watres.2015.03.026

Tawk A, Deborde M, Labanowski J, Gallard H (2015) Chlorination of the $\beta$-triketone herbicides tembotrione and sulcotrione: kinetic and mechanistic study, transformation products identification and toxicity. Wat Res 76:132-142. doi:10.1016/j. watres.2015.02.060

Wiszniowski J, Ter Halle A, Richard C, Hitmi A, Ledoigt G (2009) Photodegradation product of sulcotrione and the physiological response of maize (Zea mays) and white mustard (Sinapis alba. Chemosphere 74:1224-1230. doi:10.1016/j.chemosphere.2008.11.017

Yixin Y, Hongbin C, Pai P, Hongmiao B (2014) Degradation and transformation of atrazine under catalyzed ozonation process with $\mathrm{TiO} 2$ as catalyst. J Haz Mat 279:444 451. doi:10.1016/j.jhazmat.2014.07.035

Yu L, Van Eerd LL, O'Halloran I, Sikkema PH, Robinson DE (2015) Response of four fall-seeded cover crops to residues of selected herbicides. Crop Prot 75:11-17. doi:10.1016/j.cropro.2015.05.005 